\title{
Effects of Caffeine on Gluconeogenesis and Urea Synthesis Induced by $\alpha$-Adrenergic Stimulation in Suspensions of Rat Hepatocytes
}

\author{
Tadashi Kashiwagura, Takaki Kagaya, and Noriaki Takeguchi \\ Faculty of Pharmaceutical Sciences, \\ Toyama Medical and Pharmaceutical University, \\ Toyama, 930-01 Japan
}

\begin{abstract}
Effects of caffeine on gluconeogenesis and urea synthesis of rat isolated hepatocytes were investigated in the presence of hormonal agonists. Phenylephrine at $10 \mu \mathrm{M}$ stimulated 1.7 -fold gluconeogenesis and 1.9-fold (compared to control) urea synthesis from $4 \mathrm{~mm}$ glutamine. Stimulative effects of caffeine in the range from 0.1 to $10 \mathrm{~mm}$ were biphasic depending on its concentration, and it showed maxima at about $1 \mathrm{~mm}$. Caffeine at $1 \mathrm{~mm}$ stimulated 2.1-fold gluconeogenesis and 2.4-fold urea synthesis. Caffeine without phenylephrine did not stimulate both syntheses. These effects of caffeine and phenylephrine diminished in the absence of extracellular $\mathrm{Ca}^{2+}$. Results on uptake of ${ }^{45} \mathrm{Ca}^{2+}$ into hepatocytes and change in quin-2 fluorescence indicated that phenylephrine induced $\mathrm{Ca}^{2+}$ influx into the cell and consequently increased the intracellular $\mathrm{Ca}^{2+}$ concentration, $\left[\mathrm{Ca}^{2+}\right]$, and that the addition of caffeine did not further stimulate the effect of phenylephrine on $\left[\mathrm{Ca}^{2+}\right]$. Therefore, we suggest that stimulation of gluconeogenesis and urea synthesis by phenylephrine is due to increase in $\left[\mathrm{Ca}^{2+}\right]$. Since caffeine is known to inhibit phosphodiesterase, the additional stimulation of both syntheses by caffeine plus phenylephrine may be due to the synergistic effect of increases in cAMP and $\left[\mathrm{Ca}^{2+}\right]$. The increase in the rates of gluconeogenesis and urea synthesis similarly depended on the caffeine concentration. Furthermore, the ratio of [acetoacetate]/[3-OH-butyrate] which shows intramitochondrial redox state, also depended on the caffeine concentration, indicating a possible coupling of the redox function of mitochondria with $\left[\mathrm{Ca}^{2+}\right]$.
\end{abstract}

Key words: caffeine, gluconeogenesis, urea synthesis, cellular energy metabolism, isolated hepatocytes. 
In hepatocytes, hormones such as $\alpha$-adrenergic agonists, vasopressin, and angiotensin II cause an increase in cytosolic $\left[\mathrm{Ca}^{2+}\right]$, inducing various cellular functions (Williamson et al., 1981; Exton, 1985). Two different sources for the increase have been proposed: $\mathrm{Ca}^{2+}$ release from intracellular pools (CHEN et al., 1978; EXTON, 1981; Williamson et al., 1981), and $\mathrm{Ca}^{2+}$ influx from the extracellular medium (Assimacopoulos-Jeannet et al., 1977; Garrison and Borland, 1979; MAUGER et al., 1984). Methylxanthine derivatives such as theophylline and 3isobutyl-1-methylxanthine were reported to enhance the $\alpha$-adrenergic stimulation of glucose output (ChAN and Exton, 1978; Forster and Blair, 1978).

Caffeine is also a methylxanthine derivative and an important ingredient of tea and coffee. Effects of caffeine on gluconeogenesis and urea synthesis in hepatocytes have not been reported, although several studies showed that caffeine strongly potentiated the glucose stimulation of glycogen synthase phosphatase reaction (GILBOE, 1986) and that it did not affect the ATP dependent $\mathrm{Ca}^{2+}$ uptake into mitochondrial and endoplasmic reticulum pools (BURGESS et al., 1983).

Here, we studied effects of caffeine on both gluconeogenesis and urea synthesis from glutamine in rat isolated hepatocytes. Glutamine uptake into hepatocytes has been suggested not to be rate-limiting for these syntheses (JosEPH and MCGIVAN, 1978; OCHS and LARDY, 1983; Kashiwagura et al., 1985). Furthermore, we also studied effects of caffeine on cellular energy metabolism, that is, respiratory rate, mitochondrial $\left[\mathrm{NAD}^{+}\right] /[\mathrm{NADH}]$ and phosphorylation potential.

\section{MATERIALS AND METHODS}

Isolation of liver cells. Liver cells were prepared by the method of BERRY and FRIEND (1969) with modifications (CORNELL et al., 1973) from 48-h starved male rats of the Wistar strain, weighing 170-220 g. Rats were anesthetized with pentobarbital $(5 \mathrm{mg} / 100 \mathrm{~g})$. Collagenase $(0.4 \mathrm{mg} / \mathrm{ml})$ was dissolved in Krebs-Henseleit solution (KREBS and HENSELEIT, 1932). The flow rate of oxygenated perfusion solution during collagenase infusion was $40 \mathrm{ml} / \mathrm{min}$ at $37^{\circ} \mathrm{C}$. Isolated liver cells were suspended in Krebs-Henseleit saline supplemented with $2 \%$ bovine serum albumin. The suspension of cells was maintained at room temperature by gentle shaking under a $95 \% \mathrm{O}_{2}: 5 \% \mathrm{CO}_{2}$ atmosphere.

Incubation of liver cells. A $2 \mathrm{ml}$ cell suspension (about $40 \mathrm{mg}$ wet weight $/ \mathrm{ml}$ of cells) was mixed with $2 \mathrm{ml}$ of Krebs-Henseleit solution containing $8 \mathrm{~mm}$ glutamine (final $4 \mathrm{~mm}$ ) and $2 \%$ albumin. When caffeine ( $\leq 10 \mathrm{~mm}$ ) was added, the isotonicity of the cell suspension mixture was not readjusted. However, it was confirmed separately that the osmotic effect was negligibly small, in which experiment hypertonicity was generated by choline $\mathrm{Cl}$. The mixture was incubated in a $50 \mathrm{ml}$ Erlenmeyer flask with shaking (100-110 cycle/min) for $45 \mathrm{~min}$ at $37^{\circ} \mathrm{C}$. The $\mathrm{pH}$ of the cell suspension was adjusted to 7.4 or an indicated value with $\mathrm{CO}_{2}$-bicarbonate or 2-[N-morpholino]ethanesulfonic acid (MES)- $\mathrm{CO}_{2}$-bicarbonate buffer. The gas phase was $95 \% \mathrm{O}_{2}: 5 \% \mathrm{CO}_{2}$. In some experiments, the $\mathrm{pH}$ of the reaction medium 
was quickly measured before quenching.

Reactions in cells were quenched by injecting $0.4 \mathrm{ml}$ of $40 \%$ perchloric acid at the end of incubation. The flask containing samples was placed on ice. Then samples were centrifuged to remove insoluble material. The supernatant was neutralized with $2 \mathrm{M} \mathrm{K}_{2} \mathrm{CO}_{3}-0.58 \mathrm{M}$ triethanolamine and used for assay of metabolites. The dry weight of the cell suspension was determined for each preparation. A factor of 3.5 was used to convert dry weight into wet weight of cells (KASHIWAGURA et al., 1985).

Measurements of metabolites. We measured ATP enzymatically by the method of LAMPRECHT and TRAUTSCHOLD (1974), ADP by that of JAWOREK et al. (1974), glucose by that of BERGMEYER et al. (1974), urea by that of GUTMANN and BERGMEYER (1974), and acetoacetate and 3-OH-butyrate by that of WILLIAMSON $e t$ al. (1962).

Measurements of cellular respiration. The rate of oxygen consumption by cells was measured at $37^{\circ} \mathrm{C}$ with a Clark-type oxygen electrode (Rank Brothers).

Determination of inorganic phosphate. Cells were rapidly passed by centrifugation through a silicone oil layer (specific gravity 1.05, Shin-etsu Silicone K-45) into a quenching solution containing $4 \% \mathrm{HClO}_{4}$ and $10 \% \mathrm{NaCl}$. Phosphate in the quenching solution was measured by the method of YoDA and HoKIN (1970).

Measurements of ${ }^{45} \mathrm{Ca}^{2+}$ influx. The influx rate of $\mathrm{Ca}^{2+}$ into hepatocytes was measured by the method of MAUGER et al. (1984). Briefly, the cells were preincubated for $5 \mathrm{~min}$ at $37^{\circ} \mathrm{C}$ in Krebs-Henseleit solution containing $1.3 \mathrm{mM} \mathrm{Ca}^{2+}$ and $2 \%$ bovine serum albumin. A $250 \mu \mathrm{l}$ volume of the cell suspension was mixed with the same volume of Krebs-Henseleit solution containing $1.3 \mathrm{mM} \mathrm{Ca}^{2+}, 2 \%$ bovine serum albumin, $8 \mathrm{~mm}$ glutamine, and $2 \mu \mathrm{Ci} / \mathrm{ml}$ of ${ }^{45} \mathrm{CaCl}_{2}$ with a constant gas phase $\left(95 \% \mathrm{O}_{2}, 5 \% \mathrm{CO}_{2}\right)$. The amount of ${ }^{45} \mathrm{Ca}^{2+}$ taken in cells was determined at 15,45 , 75 , and $105 \mathrm{~s}$. Each $100 \mu \mathrm{l}$ of sample was rapidly filtered through a Whatman GF/C glass filter. Then the filter was washed 3 times with $4 \mathrm{ml}$ of the ice-cold washing solution containing $144 \mathrm{~mm} \mathrm{NaCl}, 5 \mathrm{~mm} \mathrm{CaCl}_{2}$, and $5 \mathrm{~mm}$ Tris- $\mathrm{HCl}$ (pH 7.4). Care was taken that the filter did not contact with air before the termination of the washing procedure. Then the radioactivity in the filter was counted.

Measurements of intracellular $\mathrm{Ca}^{2+}$ by quin-2/AM. Hepatocytes (45-50 mg wet weight $/ \mathrm{ml}$ ) was suspended in Krebs-Henseleit bicarbonate buffer containing $2 \%$ bovine serum albumin and $1.3 \mathrm{~mm} \mathrm{Ca}^{2+}$. They were preincubated at $37^{\circ} \mathrm{C}$ for $15 \mathrm{~min}$ with constant gassing $\left(95 \% \mathrm{O}_{2}, 5 \% \mathrm{CO}_{2}\right)$. Then they were incubated with $100 \mu \mathrm{M}$ quin-2-tetra(acetoxymethyl) ester (quin-2/AM) for $15 \mathrm{~min}$ at $37^{\circ} \mathrm{C}$. They were washed three times by centrifugation at $50 \times g$ for $2 \mathrm{~min}$ and diluted to $12-15 \mathrm{mg}$ wet weight $/ \mathrm{ml}$ in the fresh Krebs-Henseleit bicarbonate buffer. The resuspended cells were incubated for $10-15 \mathrm{~min}$ at $37^{\circ} \mathrm{C}$ prior to use in fluorescence measurements. Control hepatocytes were similarly treated without quin-2/AM. Change in the intensity of the free tetraanion (quin-2) of quin-2/AM fluorescence was measured at an excitation wavelength of $340 \mathrm{~nm}$ (1 nm slit) and an emission wavelength of $492 \mathrm{~nm}$ (5 nm slit) using a Hitachi Model 650-10 spectrofluorometer fitted with a magnetic stirrer and a thermostatted cell holder. The results were expressed as the 
change in fluorescence $(\mathrm{mV})$ from a base line in an arbitrary unit. The cell viability, as assessed by trypan blue exclusion test, was more than $90 \%$.

Reagents. Collagenase was obtained from Wako Pure Chem. Ind. Co., enzymes (hexokinase Type IV, glucose-6-phosphate dehydrogenase, urease, and 3OH-butyrate dehydrogenase) from Sigma, enzymes (glutamate dehydrogenase, lactate dehydrogenase, and pyruvate kinase) from Boehringer Mannheim, quin2/AM from Dojindo Laboratories, and ${ }^{45} \mathrm{CaCl}_{2}$ from Amersham.

\section{RESULTS}

The effect of caffeine on gluconeogenesis and urea synthesis in the presence of phenylephrine

Gluconeogenesis and urea synthesis from glutamine in hepatocytes have been found to be very sensitive to action of various effectors (JOSEPH and MCGIVAN, 1978; KaSHIWAGURA et al., 1985). Therefore, we used $4 \mathrm{~mm}$ glutamine as a substrate in all experiments. Figure $1 \mathrm{~A}$ and $\mathrm{B}$ show effects of caffeine on glucose and urea syntheses in the presence of $10 \mu \mathrm{M}$ phenylephrine at $\mathrm{pH}$ 7.4. In both syntheses, stimulative effects of caffeine were biphasic depending on its concentration, and it showed maxima at about $1 \mathrm{~mm}$. For studying the mechanism of stimulating effects of caffeine, we chose $1 \mathrm{~mm}$ caffeine in subsequent experiments. It was also found that caffeine per se did not disturb the enzymatic assay systems of various metabolites.

Effect of extracellular $\mathrm{Ca}^{2+}$ on the effect of caffeine

In the presence of $1.3 \mathrm{mM} \mathrm{Ca}^{2+}, 10 \mu \mathrm{M}$ phenylephrine increased 1.7 -fold the rate of gluconeogenesis and 1.9-fold that of ureagenesis compared to the control (Fig. 2). Caffeine alone did not stimulate both syntheses; however, caffeine (1 mM) plus phenylephrine $(10 \mu \mathrm{M})$ further stimulated them. The effects of phenylephrine and phenylephrine plus caffeine were abolished by $0.3 \mu \mathrm{M}$ prazosin, $\alpha$-antagonist (data not shown), indicating that the effect of caffeine was manifested through $\alpha$-agonistic effect of phenylephrine. Dibutyryl cAMP ( $\left.\mathrm{Bt}_{2} \mathrm{cAMP}\right)$ alone stimulated 1.4-fold both production; however, $\mathrm{Bt}_{2} \mathrm{cAMP}$ plus caffeine induced no further stimulation.

In the absence of $\mathrm{Ca}^{2+}$, the stimulating effects of phenylephrine and phenylephrine plus caffeine diminished completely (Fig. 2). The control rates of gluconeogenesis and ureagenesis were $0.31 \pm 0.01$ and $0.52 \pm 0.03 \mu \mathrm{mol} /(\mathrm{min} \cdot \mathrm{g}$ wet weight $)$, respectively.

$\mathrm{Ca}^{2+}$ influx in the presence and absence of caffeine

Uptake of ${ }^{45} \mathrm{Ca}^{2+}$ into hepatocytes was measured in the presence of phenylephrine, caffeine, or both (Fig. 3A). Caffeine alone was not effective. Phenylephrine greatly stimulated ${ }^{45} \mathrm{Ca}^{2+}$ uptake. No further stimulation was induced by phenylephrine plus caffeine. The rate of ${ }^{45} \mathrm{Ca}^{2+}$ uptake after the initial lag time of about $45 \mathrm{~s}$ was $12 \mathrm{pmol} /(\mathrm{min} \cdot \mathrm{g}$ wet weight) for control, 17 for $1 \mathrm{mM}$ caffeine, 60 for $10 \mu \mathrm{M}$ 
phenylephrine, and 62 for $10 \mu \mathrm{M}$ phenylephrine plus $1 \mathrm{~mm}$ caffeine.

Measurements of quin-2 fluorescence gave similar results (Fig. 3B). Phenylephrine at $10 \mu \mathrm{M}$ induced a large fluorescence change. The change was mainly
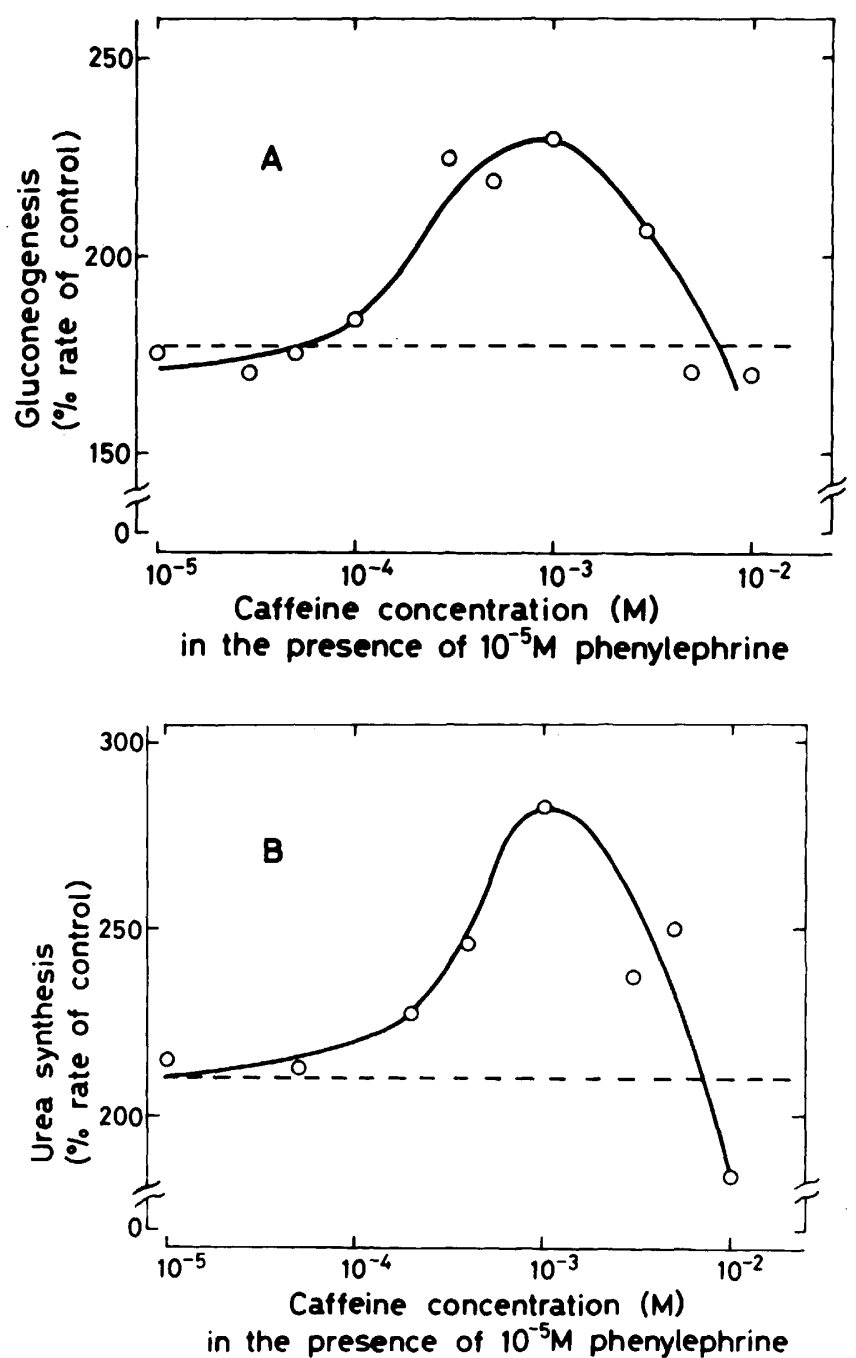

Fig. 1. The effect of caffeine in the presence of $10^{-5} \mathrm{M}$ phenylephrine on glucose (A) and urea (B) production from $4 \mathrm{~mm}$ glutamine. Values are expressed as percentages of controls. Hepatocytes were incubated for $45 \mathrm{~min}$ at $37^{\circ} \mathrm{C}$, at $18-25 \mathrm{mg}$ wet weight $/ \mathrm{ml}$ in Krebs-Henseleit buffer containing $4 \mathrm{~mm}$ glutamine and $2 \%$ bovine serum albumin. Aliquots of the cell suspension were quenched by addition of cold $\mathrm{HClO}_{4}$, rapidly cooled, and then further treated as described under MATERIALS AND METHODS. Each point is the mean of duplicate determinations in one typical experiment. Dotted lines show the levels in the absence of caffeine. 

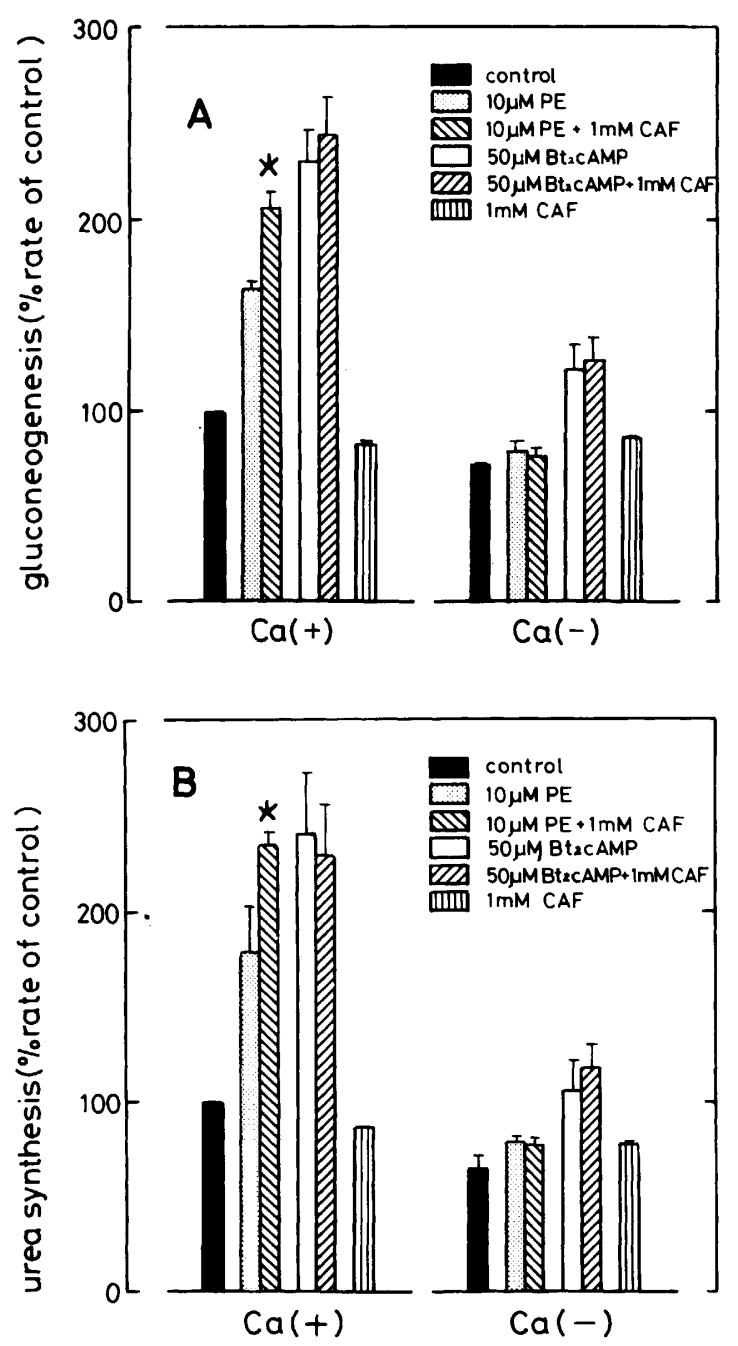

Fig. 2. The effect of $\mathrm{Ca}^{2+}$ on glucose (A) and urea (B) synthesis in the presence of various effectors. The cells were suspended as described in the legend of Fig. 1. $\mathrm{Ca}(+)$ denotes medium containing $1.3 \mathrm{~mm}$ extracellular calcium and $\mathrm{Ca}(-)$ denotes medium without $\mathrm{Ca}^{2+}$. PE, phenylephrine; $\mathrm{CAF}$, caffeine; and $\mathrm{Bt}_{2} \mathrm{CAMP}$, dibutyryl cAMP. The results are represented as mean ( $\%$ of control) values \pm S.E. for five separate determinations. ${ }^{*} p<0.05$ with respect to the result of PE ( $t$ statistic for two means).

due to $\mathrm{Ca}^{2+}$ influx from the extracellular medium $\left(1.3 \mathrm{mM} \mathrm{Ca}^{2+}\right)$, since corresponding change was very small in the absence of extracellular $\mathrm{Ca}^{2+}$ (data not shown). Caffeine in the absence of phenylephrine did not increase the intensity of fluorescence. Furthermore, caffeine did not stimulate the effect of phenylephrine. 


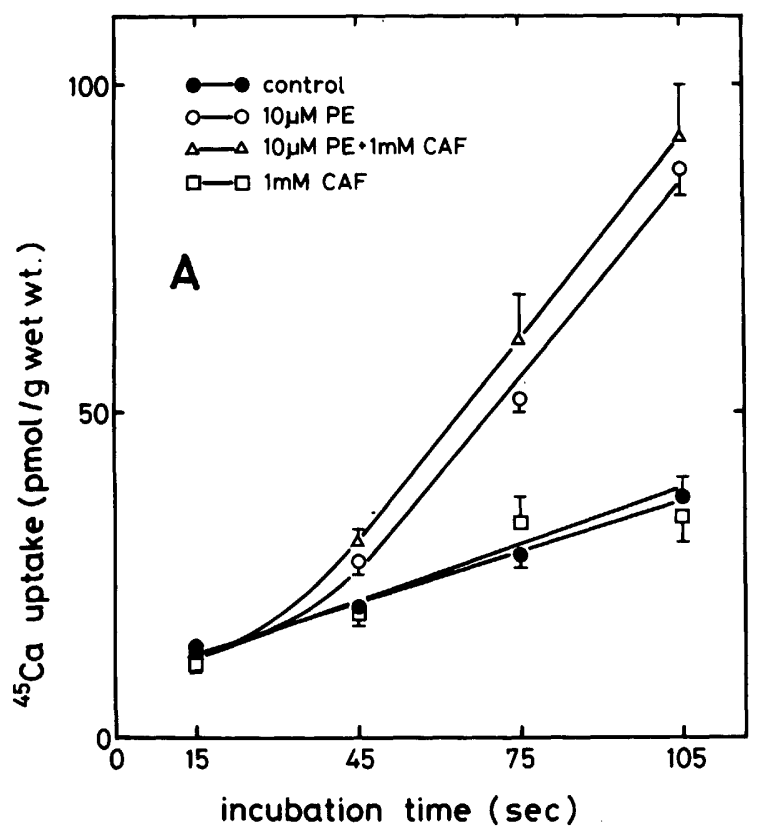

B
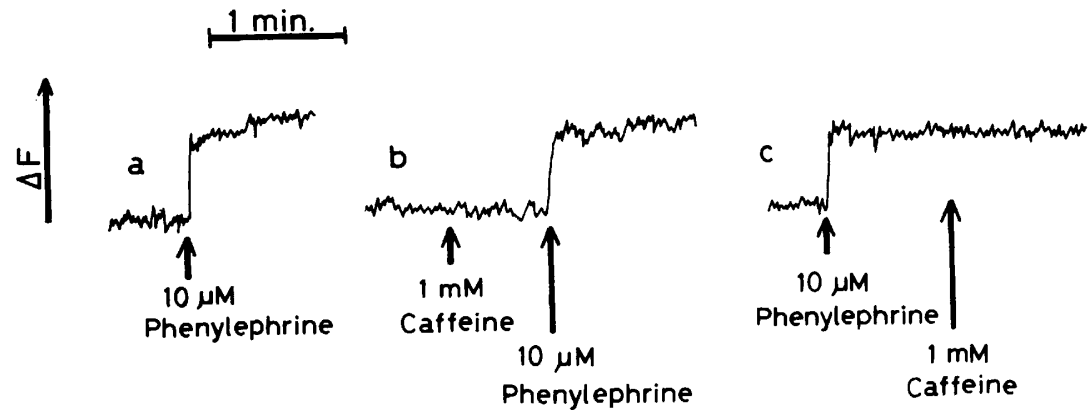

Fig. 3. A: the time course for uptake of ${ }^{45} \mathrm{Ca}^{2+}$ into rat hepatocytes. ${ }^{45} \mathrm{Ca}^{2+}(2 \mu \mathrm{Ci} / \mathrm{ml})$ were added into the suspension of hepatocytes $(20 \mathrm{mg}$ wet weight $/ \mathrm{ml})$ at zero time. Samples were taken at the indicated time, washed and counted for radioactivity as described in the MATERIALS AND METHODS. Effectors such as phenylephrine (PE) and caffeine were added together with ${ }^{45} \mathrm{Ca}^{2+}$. Each point is the mean values \pm S.E. B: the effect of phenylephrine and caffeine on fluorescence of quin- 2 . Quin-2-loaded hepatocytes were prepared as described under MATERIALS AND METHODS. The results are presented as change in the intensity of fluorescence in an arbitrary unit against time. At arrows, agents were added. 


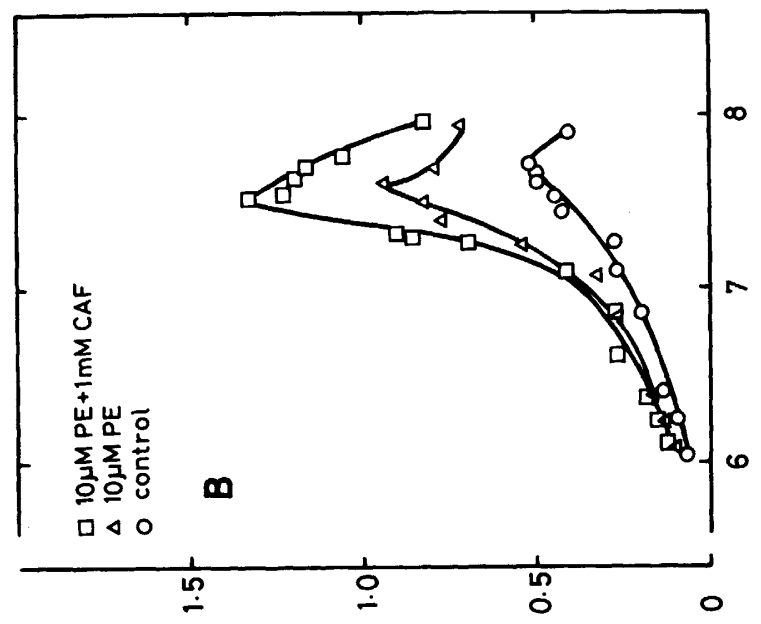

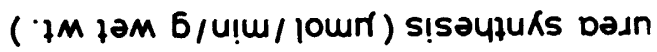

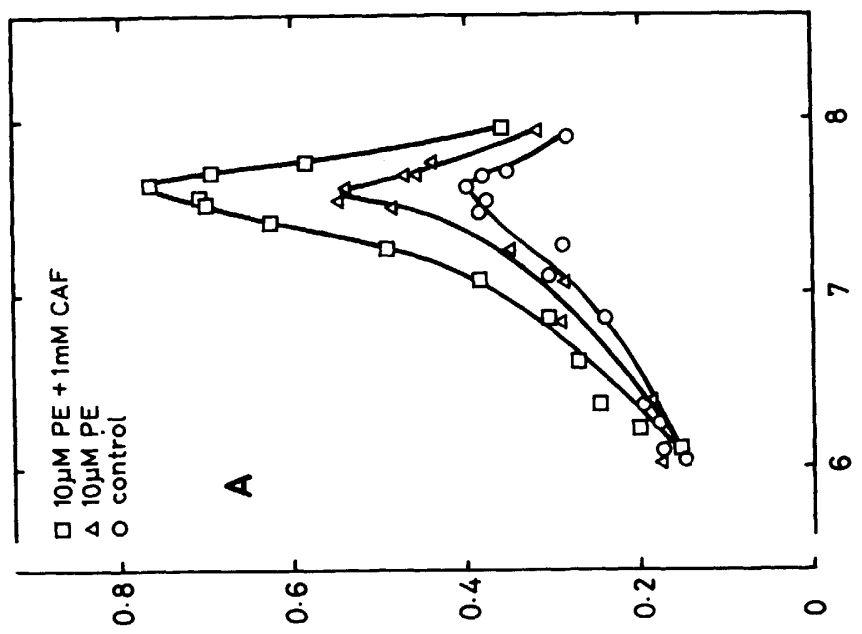

믐

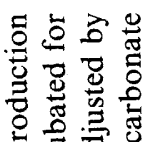

를

๑ิ.

巴ं

焉焉西

ब



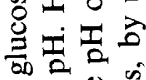

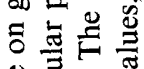

决

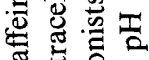

ช

$\exists$ ०

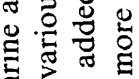

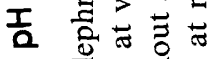

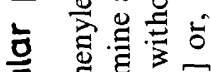

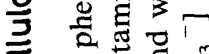

范苛

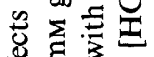

乐和

+

我

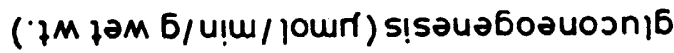




\section{Effects of extracellular $\mathrm{pH}$ on the effect of caffeine}

Results described above were obtained at $\mathrm{pH}$ 7.4. Figure 4A and $\mathrm{B}$ show effects of $\mathrm{pH}$ on glucose and urea syntheses from $4 \mathrm{~mm}$ glutamine in the presence of phenylephrine, caffeine, or both. Glucose production showed a maximum at $\mathrm{pH}$ 7.5-7.6 and urea synthesis at $\mathrm{pH} 7.3-7.6$. The former declined by $50 \%$ at $\mathrm{pH} 6.7-$ 6.8 on the acid side of the maximum and at $\mathrm{pH} 8.0$ on the alkaline side. The $50 \%$ decreases for ureagenesis occurred at $\mathrm{pH} 6.3$ on the acid side and $\mathrm{pH} 7.9$ on the alkaline side.

\section{The effect of caffeine on the phosphorylation potential}

Table 1 shows [ATP]/[ADP] ratios, concentrations of intracellular inorganic phosphate, and phosphorylation potentials in various conditions. The [ATP]/[ADP] ratio in the presence of $10 \mu \mathrm{M}$ phenylephrine plus $1 \mathrm{mM}$ caffeine was not significantly different from the control. The ratios in the various conditions listed in the table ranged from 4.5 to 6.0 . The concentration of inorganic phosphate $(2.2-2.9 \mathrm{mM})$ was the same as the control. Therefore, the phosphorylation potential ([ATP]/[ADP] $\left[\mathrm{P}_{\mathrm{i}}\right]$ ) was nearly constant and was in the range from $1.7 \times 10^{-3}$ to $2.4 \times 10^{-3} \mathrm{M}^{-1}$. These results show that the phosphorylation potentials in the various conditions were almost constant.

The effect of caffeine on the respiratory rate

The control levels of the respiratory rate in the presence and absence of $\mathrm{Ca}^{2+}$ were $5.07 \pm 1.32$ and $4.96 \pm 0.94 \mu \mathrm{mol} /(\mathrm{min} \cdot \mathrm{g}$ wet weight), respectively. Caffeine

Table 1. The phosphorylation values in the presence of various effectors.

\begin{tabular}{|c|c|c|c|c|}
\hline Treatment & $\frac{[\mathrm{ATP}]}{[\mathrm{ADP}]}$ & & {$\left[\mathrm{P}_{\mathrm{i}}\right](\mathrm{mM})$} & $\frac{[\mathrm{ATP}]}{[\mathrm{ADP}]\left[\mathrm{P}_{\mathrm{i}}\right]}\left(\mathrm{M}^{-1}\right)$ \\
\hline Control $(+)$ & $4.64 \pm 0.17$ & (11) & $2.49 \pm 0.16$ & $1.86 \times 10^{3}$ \\
\hline Control (-) & $4.53 \pm 0.32$ & $(5)$ & $2.40 \pm 0.07$ & $1.89 \times 10^{3}$ \\
\hline $10 \mu \mathrm{M}$ PE $(+)$ & $4.79 \pm 0.20$ & (8) & $2.16 \pm 0.06$ & $2.22 \times 10^{3}$ \\
\hline $10 \mu \mathrm{M}$ PE $(-)$ & $4.65 \pm 0.18$ & (3) & $2.24 \pm 0.14$ & $2.08 \times 10^{3}$ \\
\hline $10 \mu \mathrm{M}$ PE $+1 \mathrm{~mm}$ CAF $(+)$ & $4.96 \pm 0.15$ & (8) & $2.94 \pm 0.12^{\mathrm{a}}(4)$ & $1.69 \times 10^{3}$ \\
\hline $10 \mu \mathrm{M}$ PE $+1 \mathrm{~mm}$ CAF $(-)$ & $4.69 \pm 0.24$ & (3) & $2.63 \pm 0.33$ & $1.78 \times 10^{3}$ \\
\hline $50 \mu \mathrm{MBt}_{2} \mathrm{cAMP}(+)$ & $5.91 \pm 0.26^{\mathrm{a}}$ & (3) & $2.70 \pm 0.10$ & $2.19 \times 10^{3}$ \\
\hline $50 \mu \mathrm{MBt}{ }_{2} \mathrm{cAMP}(-)$ & $5.39 \pm 0.24$ & (3) & $2.27 \pm 0.16$ & $2.37 \times 10^{3}$ \\
\hline $50 \mu \mathrm{M} \mathrm{Bt}{ }_{2} \mathrm{cAMP}+1 \mathrm{mM} \mathrm{CAF}(+)$ & $4.86 \pm 0.27$ & (3) & $2.55 \pm 0.09$ & $1.91 \times 10^{3}$ \\
\hline $50 \mu \mathrm{MBt}_{2} \mathrm{cAMP}+1 \mathrm{mM} \mathrm{CAF}(-)$ & $4.75 \pm 0.41$ & (3) & $2.20 \pm 0.10$ & $2.16 \times 10^{3}$ \\
\hline $1 \mathrm{~mm} \mathrm{CAF}(+)$ & $4.57 \pm 0.74$ & (3) & $2.39 \pm 0.24$ & $1.91 \times 10^{3}$ \\
\hline $1 \mathrm{mM} \mathrm{CAF} \mathrm{(-)}$ & $4.63 \pm 0.55$ & (3) & $2.31 \pm 0.26$ & $2.00 \times 10^{3}$ \\
\hline
\end{tabular}

${ }^{\mathrm{a}} p<0.05$ with respect to control ( $t$ statistics for two means). ( + ), with extracellular $1.3 \mathrm{mM} \mathrm{Ca}^{2+} ;(-)$, without extracellular $\mathrm{Ca}^{2+} ; \mathrm{PE}$, phenylephrine; $\mathrm{CAF}$, caffeine; $\mathrm{Bt}_{2} \mathrm{cAMP}$, dibutyryl cAMP. Data are the mean \pm S.E. (number of experiments). 
Table 2. The effect of caffeine on oxygen consumption in hepatocytes incubated with $4 \mathrm{~mm}$ glutamine.

\begin{tabular}{|c|c|}
\hline Treatment & Respiratory rate $(\%)$ \\
\hline Control $(+)$ & 100 \\
\hline Control (-) & 100 \\
\hline $10 \mu \mathrm{M} \mathrm{PE}(+)$ & $118 \pm 2^{\mathrm{a}}$ \\
\hline $10 \mu \mathrm{M}$ PE $(-)$ & $100 \pm 4$ \\
\hline $10 \mu \mathrm{M} \mathrm{PE}+1 \mathrm{~mm} \mathrm{CAF}(+)$ & $131 \pm 2^{\mathrm{a}, \mathrm{b}}(3)$ \\
\hline $10 \mu \mathrm{M} \mathrm{PE}+1 \mathrm{~mm} \mathrm{CAF}(+)$ & $108 \pm 2$ \\
\hline $1 \mathrm{~mm} \mathrm{CAF}(+)$ & $107 \pm 2^{a}$ \\
\hline $1 \mathrm{~mm} \mathrm{CAF}(-)$ & $105 \pm 1$ \\
\hline
\end{tabular}

Hepatocytes (18-25 mg wet weight/ml) were preincubated for $10 \mathrm{~min}$ with each of the indicated effectors at $37^{\circ} \mathrm{C}$. Aliquots were then transferred to a sealed thermostated cuvette and the rate of oxygen uptake was monitored with a Clark-type oxygen electrode for the next $10-15$ min. ${ }^{\text {a }} p<0.05$ with respect to control ( $t$ statistics for two means). ${ }^{\mathrm{b}} p<0.05$ with respect to $10 \mu \mathrm{M}$ PE. (+), with extracellular $1.3 \mathrm{mM} \mathrm{Ca}^{2+} ;(-)$, without extracellular $\mathrm{Ca}^{2+} ; \mathrm{PE}$, phenylephrine; CAF, caffeine. Data are the mean \pm S.E. (number of experiments).

Table 3. The effect of caffeine on redox states of intramitochondria in the presence of various effectors.

\begin{tabular}{|c|c|}
\hline \multirow{2}{*}{ Treatment } & [acetoacetate] \\
\hline & [3-OH-butyrate] \\
\hline Control $(+)$ & $5.58 \pm 0.42$ \\
\hline Control $(-)$ & $5.29 \pm 0.36$ \\
\hline $10 \mu \mathrm{M}$ PE $(+)$ & $3.96 \pm 0.44^{\mathrm{a}}$ \\
\hline $10 \mu \mathrm{M}$ PE $(-)$ & $4.91 \pm 0.33$ \\
\hline $10 \mu \mathrm{M}$ PE +1 mм CAF $(+)$ & $2.24 \pm 0.31^{\mathrm{a}, \mathrm{b}}$ \\
\hline $10 \mu \mathrm{M}$ PE +1 mм CAF $(-)$ & $5.35 \pm 0.37$ \\
\hline $50 \mu \mathrm{MBt}_{2} \mathrm{cAMP}(+)$ & $2.13 \pm 0.45^{\mathrm{a}}$ \\
\hline $50 \mu \mathrm{M} \mathrm{Bt}_{2} \mathrm{cAMP}(-)$ & $4.27 \pm 0.07^{\mathrm{a}}$ \\
\hline $50 \mu \mathrm{MBt}{ }_{2} \mathrm{cAMP}+1 \mathrm{mM} \mathrm{CAF}(+)$ & $2.22 \pm 0.51^{\mathrm{a}}$ \\
\hline $50 \mu \mathrm{MBt}{ }_{2} \mathrm{cAMP}+1 \mathrm{~mm} \mathrm{CAF}(-)$ & $4.82 \pm 0.88$ \\
\hline $1 \mathrm{~mm} \mathrm{CAF}(+)$ & $6.10 \pm 0.88$ \\
\hline $1 \mathrm{~mm} \mathrm{CAF}(-)$ & $6.06 \pm 0.35$ \\
\hline
\end{tabular}

For measurements of [acetoacetate]/[3-OH-butyrate] ratio, hepatocytes were incubated as described in the legend of Fig. 1 and metabolites were assayed as described under MATERIALS AND METHODS. Values are mean \pm S.E. (number of experiments). ${ }^{\mathrm{a}} p<0.05$ with respect to control ( $t$ statistics for two means) and ${ }^{\mathrm{b}} p<0.05$ with respect to PE in paired experiments. Notations and abbreviations are the same as in the legend of Table 1. 


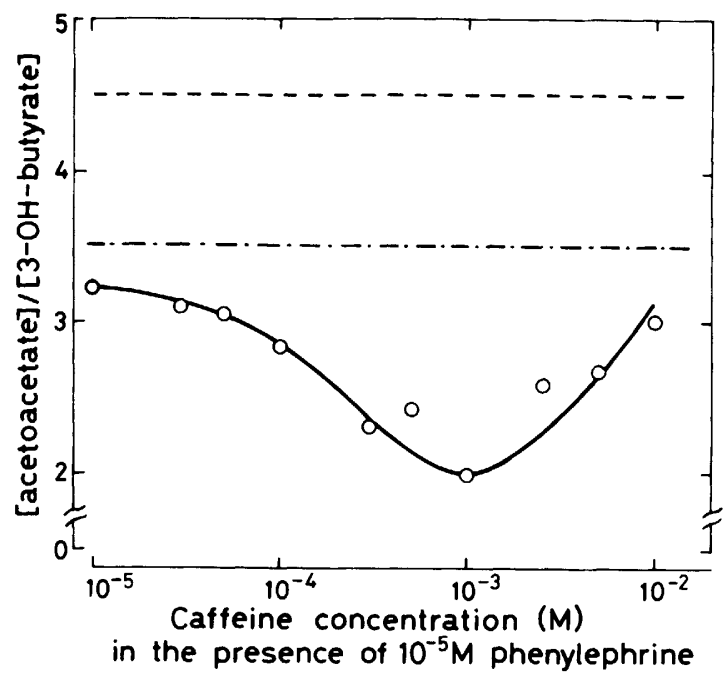

Fig. 5. Effects of caffeine on the ratio of [acetoacetate]/[3-OH-butyrate] in the presence of $10^{-5} \mathrm{M}$ phenylephrine. The dotted line shows the control and the broken line shows the level at $10 \mu \mathrm{M}$ phenylephrine.

slightly stimulated the respiratory rate (Table 2). Phenylephrine in the presence of $\mathrm{Ca}^{2+}$ stimulated 1.18-fold oxygen consumption compared to control. Phenylephrine plus caffeine stimulated 1.31-fold the rate. However, this effect of phenylephrine diminished in the absence of extracellular $\mathrm{Ca}^{2+}$.

\section{The effect of caffeine on intramitochondrial redox state}

Measurements of 3-OH-butyrate and acetoacetate in hepatocytes showed that phenylephrine plus caffeine decreased the ratio of [acetoacetate]/[3-OH-butyrate] from 5.58 (control) to 2.24 (Table 3). This result indicated that the intramitochondrial redox state shifted to more reductive compared to control. However, the ratio did not change in the absence of $\mathrm{Ca}^{2+}$. Caffeine alone shifted slightly the redox state to oxidative. $\mathrm{Bt}_{2} \mathrm{cAMP}$ shifted the redox state to reductive in the presence of $\mathrm{Ca}^{2+}$.

Figure 5 shows dose-dependent effects of caffeine on the ratio of [acetoacetate]/ [3-OH-butyrate] in the presence of $10 \mu \mathrm{M}$ phenylephrine. The change in the intramitochondrial redox state was a mirror image of the changes in gluconeogenesis and urea synthesis (Fig. 1A and B). At $1 \mathrm{~mm}$ caffeine, the rates of both syntheses showed maxima and the redox state shifted to the most reduced one.

\section{DISCUSSION}

Methylxanthines such as theophylline and 1-methyl-3-isobutylxanthine potentiate effects of $\alpha$-adrenergic stimulation in liver. The effect has been attributed to change in $\left[\mathrm{Ca}^{2+}\right]$ and not to change in [CAMP] (CHERRINGTON et al., 1976; CHAN and ExTON, 1978; Forster and Blair, 1978; GARrison and Borland, 1979). We 
found that stimulating effects of caffeine on both gluconeogenesis and urea production from glutamine completely depended on the action of phenylephrine (Figs. 1 and 2, and effects of prazosin). However, these effects of caffeine diminished in the absence of extracellular $\mathrm{Ca}^{2+}$ (Fig. 2). Phenylephrine induced influx of extracellular $\mathrm{Ca}^{2+}$, inducing a rise in the intracellular $\mathrm{Ca}^{2+}$ concentration (Fig. 3). This effect of phenylephrine was observed when the extracellular $\mathrm{Ca}^{2+}$ concentration was higher than $0.1 \mathrm{~mm}$ (data not shown). This finding was consistent with previous results in which $\mathrm{Ca}^{2+}$ influx by norepinephrine was studied in liver (MAUGER et al., 1984). Stimulative effects of caffeine on both syntheses were biphasic, i.e., increasing and decreasing with increasing the caffeine concentration (Fig. 1). Their maxima occurred at about $1 \mathrm{~mm}$ caffeine. For the decreasing effect of caffeine at higher concentrations, although we did not explore the actual reasons, nonspecific inhibitory effects on various enzymatic systems for both syntheses are considered.

Effects of phenylephrine and phenylephrine plus caffeine depended on the extracellular $\mathrm{pH}$ (Fig. 4). Both syntheses showed the highest rate at about $\mathrm{pH} 7.7$, which was slightly more alkaline than physiological. These stimulating effects would be due to the elevated cytosolic $\mathrm{Ca}^{2+}$ concentration, which has been suggested to be maintained by assorted movements of $\mathrm{Ca}^{2+}$ via $\mathrm{Ca}^{2+}$ channel and $\mathrm{CA}^{2+} / \mathrm{OH}^{-}$ symport or $\mathrm{Ca}^{2+} / \mathrm{H}^{+}$antiport in the plasma membrane and also by initial rapid $\mathrm{Ca}^{2+}$ release from intracellular $\mathrm{Ca}^{2+}$ stores (BLACKMORE et al., 1984; MAUGER et al., 1984). The latter was triggered by increase in myo-inositol triphosphate induced by adrenergic agonists (JOSEPH et al., 1984; CHAREST et al., 1985).

Although phenylephrine induced the increase in intracellular $\left[\mathrm{Ca}^{2+}\right]$, further increase was not observed by addition of caffeine (Fig. 3A and B). CHAN and ExTON (1978) reported that epinephrine or 1-methyl-3-isobutylxanthine did not induce a rise in cAMP in hepatocytes, but epinephrine plus 1-methyl-3-isobutylxanthine induced a large rise in cAMP. Furthermore, it was reported that caffeine inhibited phosphodiesterase, for example, in guinea pig colon and rat erythrocyte (PoCH and UMFAHRER, 1976) and dog tracheal smooth muscle (Polson et al., 1978) and that caffeine did not change calcium accumulation by microsomes (BATRA and DANIEL, 1971). Based on these reports, although we did not measure the intracellular cAMP, phenylephrine plus caffeine may increase intracellular cAMP, which stimulates gluconeogenesis and urea synthesis in association with the increase in intracellular free $\left[\mathrm{Ca}^{2+}\right]$ induced by phenylephrine. Another possibility was considered that trace amount of binding calcium within the cell was released by caffeine.

We could not find the stimulating effect of caffeine in the presence of angiotensin II or vasopressin (data not shown). This finding may reflect the recent finding that the pattern of change in aequorin bioluminescence induced by phenylephrine in hepatocytes was different from that induced by vasopressin or angiotensin II, suggesting that the mode of action of phenylephrine on cytoplasmic free calcium concentration differs from that of either vasopressin or angiotensin II (Mine et al., 1986). 
Phenylephrine-induced increase in syntheses of glucose and urea utilized more than $3.1 \mu \mathrm{mol} \mathrm{ATP} /(\min \cdot \mathrm{g}$ wet weight $)$. The phenylephrine-induced increase in oxygen uptake yields $5.5 \mu \mathrm{mol} \mathrm{ATP} /(\mathrm{min} \cdot \mathrm{g}$ wet weight $)$ under the assumption that one $\mathrm{O}_{2}$ molecule yields 6 ATP. These results indicated that both synthetic pathways were supplied fully with ATP energy. Similarly, the additional increase caused by caffeine in production of glucose and urea (i.e., the difference of effects between phenylephrine plus caffeine and phenylephrine) utilized more $1.7 \mu \mathrm{mol} \mathrm{ATP} /(\mathrm{min} \cdot \mathrm{g}$ wet weight). Corresponding increase in oxygen uptake yields $4.0 \mu \mathrm{mol} \mathrm{ATP} /(\mathrm{min} \cdot \mathrm{g}$ wet weight). Effects of caffeine on hormonal responses were almost parallel in both glucose and urea productions (Fig. 1), indicating that the effects of caffeine had no selectivity for energy supply to both syntheses.

As shown in Table 1, phosphorylation potentials of hepatocytes were almost constant in various conditions, suggesting that respiratory rate increased to maintain a constant level for ATP supply even under acceleration of both synthetic pathways accompanied with higher ATP consumption. Consequently, phosphorylation potential may be the most important factor in the cellular energy metabolism (Wilson et al., 1974; ERECINSKA and WiLSON, 1982).

Phenylephrine and phenylephrine plus caffeine in the presence of extracellular $\mathrm{Ca}^{2+}$ - decreased the intramitochondrial $\left[\mathrm{NAD}^{+}\right] /[\mathrm{NADH}]$ ratio, which is estimated from the change in the ratio of [acetoacetate]/[3-OH-butyrate] (WILLIAMSON et al., 1967) (Fig. 5 and Table 3). The decrease in the ratio of $\left[\mathrm{NAD}^{+}\right] /[\mathrm{NADH}]$ may assist gluconeogenesis and urea synthesis. Recently, effectors that elevate the intracellular $\mathrm{Ca}^{2+}$ were shown to induce reduction of pyridine nucleotide in hepatocytes and gastric glands (CHAREST et al., 1983; CHEw, 1986). These facts are similar to ours. Although it is not clear how clacium exerts the defined effect on the $\left[\mathrm{NAD}^{+}\right] /$ [NADH] ratio in liver cells, the influence of calcium on the mitochondrial oxidationreduction state may be an importanct factor in regulating cellular functions via several pyridine nucleotide-linked reactions and in maintaining the phosphorylation state of the adenine nucleotide system.

This work was supported in part by a Grant-in-Aid for Scientific Research from the Ministry of Education, Science and Culture of Japan.

\section{REFERENCES}

Assimacopoulos-Jeannet, F. D., Blackmore, P. F., and Exton, J. H. (1977) Studies on $\alpha$ adrenergic activation of hepatic glucose output. J. Biol. Chem., 252: 2662-2669.

Batra, S. C. and DANiEL, E. E. (1971) Effect of multivalent cations and drugs on Ca uptake by the rat myometrial microsomes. Comp. Biochem. Physiol. A, 38: 285-300.

Bergmeyer, H. U., Bernt, E., Schmidt, F., and Stork, H. (1974) D-Glucose. Determination with hexokinase and glucose-6-phosphate dehydrogenase. In: Methods of Enzymatic Analysis, ed. by BergmeYer, H. U., Verlag Chemie/Academic Press, New York, San Francisco, London, Vol. 3, pp. 1196-1201.

Berry, M. N. and Friend, D. S. (1969) High-yield preparation of isolated rat liver 
parenchymal cells. J. Cell Biol., 43: 506-520.

Blackmore, P. F., Waynick, L. E., Blackman, G. E., Graham, C. W., and Sherry, R. S. (1984) $\alpha$ - and $\beta$-adrenergic stimulation of parenchymal cell $\mathrm{Ca}^{2+}$ influx. J. Biol. Chem., 259: 12322-12325.

Burgess, G. M., McKinney, J. S., Fabiato, A., Leslie, B. A., and Putney, J. W., Jr. (1983) Calcium pools in saponin-permeabilized guinea pig hepatocytes. J. Biol. Chem., 258: $15336-15345$.

Chan, T. M. and Exton, J. H. (1978) Studies on $\alpha$-adrenergic activation of hepatic glucose output. Studies on $\alpha$-adrenergic inhibition of hepatic pyruvate kinase and activation of gluconeogenesis. J. Biol. Chem., 253: 6393-6400.

Charest, R., Blackmore, P. F., Berthon, B., and Exton, J. H. (1983) Changes in free cytosolic $\mathrm{Ca}^{2+}$ in hepatocytes following $\alpha_{1}$-adrenergic stimulation. Studies on quin-2loaded hepatocytes. J. Biol. Chem., 258: 8769-8773.

Charest, R., Prpic, V., Exton, J. H., and Blackmore, P. F. (1985) Stimulation of inositol trisphosphate formation in hepatocytes by vasopressin, adrenaline and angiotensin II and its relationship to changes in cytosolic free $\mathrm{Ca}^{2+}$. Biochem. J., 227: 79-90.

Chen, J.-L. J., BABCOCK, D. F., and LARDY, H. L. (1978) Norepinephrine, vasopressin, glucagon, and A23187 induce efflux of calcium from an exchangeable pool in isolated rat hepatocytes. Proc. Natl. Acad. Sci. U.S.A., 75: 2234-2238.

Cherrington, A. D., Assimacopoulos, F. D., Harper, S. C., Corbin, J. D., Park, C. R., and Exton, J. H. (1976) Studies on the $\alpha$-adrenergic activation of hepatic glucose output. II. Investigation of the roles of adenosine $3^{\prime}: 5^{\prime}$-monophosphate-dependent protein kinase in the actions of phenylephrine in isolated hepatocytes. J. Biol. Chem., 251: 5209-5218.

CHEw, C. S. (1986) Cholecystokinin, carbachol, gastrin, histamine, and forskolin increase $\left[\mathrm{Ca}^{2+}\right]_{\mathrm{i}}$ in gastric glands. Am. J. Physiol., 250, G814-G823.

Cornell, N. W., Lund, P., Hems, R., and Krebs, H. A. (1973) Acceleration of gluconeogenesis from lactate by lysine. Biochem. J., 134: 671-672.

ERECINSKA, M. and WiLsON, D. F. (1982) Regulation of cellular energy metabolism. $J$. Membr. Biol., 70: 1-14.

Exton, J. H. (1981) Molecular mechanisms involved in $\alpha$-adrenergic responses. Mol. Cell. Endocrinol., 23: 233-264.

Exton, J. H. (1985) Mechanisms involved in $\alpha$-adrenergic phenomena. Am. J. Physiol., 248: E633-E647.

Forster, J. L. and Blair, J. B. (1978) Acute hormonal control of pyruvate kinase and lactate formation in the isolated rat hepatocyte. Arch. Biochem. Biophys., 189: 263276.

Garrison, J. C. and Borland, M. K. (1979) Regulation of mitochondrial pyruvate carboxylation and gluconeogenesis in rat hepatocytes via an $\alpha$-adrenergic, adenosine $3^{\prime}: 5^{\prime}$-monophosphate-independent mechanism. J. Biol. Chem., 254: 1129-1133.

GiLBOњ, D. P. (1986) The mechanism of caffeine-enhanced glucose stimulation of liver glycogen synthase phosphatase activity. Biochem. Pharmacol., 35: 2097-2105.

Gutmann, I. and BergmeYer, H. U. (1974) Determination of urea with glutamate dehydrogenase as indicator enzyme. In: Methods of Enzymatic Analysis, ed. by Bergmeyer, H. U., Verlag Chemie/Academic Press, New York, San Francisco, London, Vol. 4, pp. 1791-1798.

JAWOREK, D., Gruber, W., and BergmeYer, H. U. (1974) Adenosine- 5 '-dephosphate and adenosine-5'-monophosphate. In: Methods of Enzymatic Analysis, ed. by BERGMEYER, 
H. U., Verlag Chemie/Academic Press, New York, San Francisco, London, Vol. 4, pp. $2127-2131$.

JoSEPH, S. K. and MCGivan, J. D. (1978) The effect of ammonium chloride and glucagon on the metabolism of glutamine in isolated liver cells from starved rats. Biochim. Biophys. Acta, 543: 16-28.

Joseph, S. K., Thomas, A. P., Williams, R. J., Irvine, R. F., and Williamson, J. R. (1984) myo-Inositol 1,4,5-trisphosphate. A second messenger for the hormonal mobilization of intracellular $\mathrm{Ca}^{2+}$ in liver. J. Biol. Chem., 259: 3077-3081.

Kashiwagura, T., Erecinska, M., and Wilson, D. F. (1985) pH dependence of hormonal regulation of gluconeogenesis and urea synthesis from glutamine in suspensions of hepatocytes. J. Biol. Chem., 260: 407-414.

KREBS, H. A. and Henseleit, K. (1932) Untersuchungen uber die Harnstoffbildung in Tierkorper. Hoppe-Seyler's Z. Physiol. Chem., 210: 33-66.

LaMPRECHT, W. and Trautschold, I. (1974) Adenosine-5'-triphosphate: Determination with hexokinase and glucose-6-phosphate dehydrogenase. In: Methods of Enzymatic Analysis, ed. by Bergmeyer, H. U., Verlag Chemie/Academic Press, New York, San Francisco, London, Vol. 4, pp. 2101-2110.

Mauger, J.-P., Poggioli, J., Guesdon, F., and Claret, M. (1984) Noradrenaline, vasopressin and angiotensin increase $\mathrm{Ca}^{2+}$ influx by opening a common pool of $\mathrm{Ca}^{2+}$ channels in isolated rat liver cells. Biochem. J., 221: 121-127.

Mine, T., Kojima, I., Kimura, S., and Ogata, E. (1986) Comparison of the changes in cytoplasmic free calcium concentration induced by phenylephrine, vasopressin and angiotensin II in hepatocytes. Biochem. Biophys. Res. Commun., 140: 107-113.

OCHS, R. S. and LaRdY, H. A. (1983) Catecholamine stimulation of hepatic gluconeogenesis at the site between pyruvate and phosphoenolpyruvate. J. Biol. Chem., 258: 9956-9962.

PoCH, G. and UNFAHRER, W. (1976) Differentiation of intestinal smooth muscle relaxation caused by drugs that inhibit phosphodiesterase. Naunyn-Schmiedebergs Arch. Pharmacol., 293: 257-268.

Polson, J. B., KrZanowski, J. J., FitzPatrick, D. F., and Szentivanyi, A. (1978) Studies on the inhibition of phosphodiesterase-catalyzed cyclic AMP and cyclic GMP breakdown and relaxation of canine tracheal smooth muscle. Biochem. Pharmacol., 27: 254 256.

Williamson, J. R., COOPER, R. H., and HoEK, J. B. (1981) Role of calcium in the hormonal regulation of liver metabolism. Biochim. Biophys. Acta, 639: 243-295.

Williamson, D. H., Lund, P., and KreBs, H. A. (1967) The redox state of free nicotinamide-adenine dinucleotide in the cytoplasm and mitochondria of rat liver. Biochem. J., 103: 514-527.

Williamson, D. H., Mellanby, J., and Krebs, H. A. (1962) Enzymic determination of $\mathrm{D}(-)-\beta$-hydroxybutyric acid and acetoacetic acid in blood. Biochem. J., 82: 90-96.

Wilson, D. F., Stubbs, M., Veech, R. L., Erecinska, M., and Krebs, H. A. (1974) Equilibrium relations between the oxidation-reduction reactions and the adenosine triphosphate synthesis in suspensions of isolated liver cells. Biochem. J., 140: 5764.

YoDA, A. and HoKIN, L. (1970) On the reversibility of binding of cardiotonic steroids to a partially purified $(\mathrm{Na}+\mathrm{K})$-activated adenosinetriphosphatase from beef brain. Biochem. Biophys. Res. Commun., 40: 880-886. 